\title{
Using factor analysis to validate a questionnaire to explore self- regulation in learner-generated digital media (LGDM) assignments in science education
}

\author{
Jorge Reyna \\ Faculty of Science, University of Technology Sydney \\ Jose Hanham \\ School of Education, Western Sydney University
}

Panos Vlachopoulos

Faculty of Arts, Macquarie University

Peter Meier

University of Technology Sydney

\begin{abstract}
This research is a validation study of a survey instrument to assess student self-regulation which aims to fill a methodological gap by capturing self-regulation processes while completing learner-generated digital media (LGDM) assignments. For this purpose, the study developed and validated a self-regulation learning questionnaire. Data were gathered from seven science subjects (Years 1 to $3, n=341$ ) which used LGDM assignments during Semester 1, 2017. Students were asked to complete a 40-item online questionnaire. The questionnaire was administered at three times during the semester (Weeks 2, 6, and 10). Exploratory factor analysis was used to identify factor structures, followed by confirmatory factor analysis to test the validity of the constructs defined by exploratory factor analysis. Analysis of the data revealed a ten-factor structure - six concerning self-regulation, two concerning student attitudes towards LGDM assignments, one concerning assignment ownership, and one concerning assignment motivation. The variables empirically verified in this study have important practical implications, as they could provide educators with the direction in which to target interventions to improve learners' experiences with LDGM. The study findings also contribute to the field by providing scholars with a validated research instrument that can be used in future studies.
\end{abstract}

\section{Introduction}

Learner-generated digital media (LGDM) refers to digital artefacts developed by students as an assessment task which communicates a message to an audience, such as their peers or the general public (Reyna, Meier, Geronimo, \& Rodgers, 2016). It has been used for the last decade in higher education as a vehicle of reflection for pre-service teachers (Hoban, Nielsen, \& Shepherd, 2015; Kearney, 2009, 2013; Kearney \& Schuck, 2005). In other disciplines, such as marketing and accounting (Greene \& Crespi, 2012), human geography (Anderson, 2013a), pharmacy (Pearce, 2014; Pearce \& Vanderlelie, 2016), computing (Powell \& Robson, 2014), medical imaging (Braun, 2017), and physiotherapy (Coulson \& Frawley, 2017), LGDM has focused on teaching subject content. Nonetheless, examination of the literature suggests that LGDM is in its embryonic stages and is under-researched and under-theorised (Campbell \& Cox, 2018; Hakkarainen, 2009; Hoban et al., 2015; Potter \& McDougall, 2017).

The main issue with LGDM assignments is the lack of a practical model for designing, implementing, and evaluating the assessment task in the classroom. Many studies on LGDM do not rely on a framework to approach assessment design (Anderson, 2013a; Braun, 2017; Coulson \& Frawley, 2017; Greene \& Crespi, 2012; Pearce \& Vanderlelie, 2016; Powell \& Robson, 2014). Other studies use frameworks contextualised within the discipline of education (Kearney, 2009, 2013), and it is unclear how well these frameworks extrapolate to other subjects, such as sciences. Finally, some studies use semiotic theory (Hoban \& Nielsen, 2013; Nielsen, Hoban, \& Hyland, 2017), semantic density theory (Georgiou, Nielsen, Doran, Turney, \& Jones, 2017), and instructional design models (Cox, Vasconcelos, \& Holdridge, 2010), but these approaches often overlook the need for student training to develop digital media production skills. 
From the evaluation perspective, typical problems with LGDM research are the small sample sizes used in studies and the qualitative nature of methods to evaluate the intervention. Many LGDM researchers have used qualitative surveys and open-ended questions (Cox et al., 2010; Greene \& Crespi, 2012; Kearney, 2013; Pearce \& Vanderlelie, 2016), analysis of surveys and marks attained (Braun, 2017), or purely qualitative comments from interviews (Anderson, 2013b; Hoban \& Nielsen, 2013). The surveys reported in the research literature often have not been previously validated to ensure correlation between the questions asked and the constructs under study. While qualitative data provides some valuable insights into student perceptions, its results cannot be generalised to the classroom. Along with small sample size and lack of a standardised evaluation model, the qualitative nature of these investigations makes comparisons between studies problematic. Additionally, different media types used in LGDM - such as audio podcast, digital story, animation, or video - require different production skills, adding an extra layer of complexity when comparing studies.

This research used a comprehensive model, the LGDM implementation framework (Reyna \& Meier, 2018), as a theoretical underpinning to guide the systematic design of the LGDM task. Previous studies have used the LGDM framework in science education (Reyna, Hanham, \& Meier, 2018c; Reyna, Horgan, Ramp, \& Meier, 2017; Reyna et al., 2016). Elements of the framework include pedagogies, student training, video hosting, marking scheme, group work, feedback, reflection, and evaluation. Mapping of these elements against self-regulation subscales sought to capture the dynamic nature of students' self-regulation while completing LGDM assignments.

The goals of the research were to explore and validate the psychometric properties of a survey instrument designed to measure self-regulation where the LGDM implementation framework had been used to guide assignment design and implementation in science subjects. Additionally, the study included measurements of student attitudes towards the use of digital media creation for learning, use of digital media in their careers, and assignment motivation and ownership.

\section{Literature review}

Self-regulation is a psychological construct defined as judgements, feelings, and activities that are planned and implemented to achieve personal goals (Zimmerman, 2002) and that are essential for succeeding in academic, professional, and personal life. From the lens of social cognitive theory, self-regulation is a mixture of personal, behavioural, and environmental processes that interact (Bandura, 1991). There is research evidence suggesting that self-regulation is related to student academic performance and achievement (Azevedo \& Cromley, 2004; Broadbent \& Poon, 2015; Richardson, Abraham, \& Bond, 2012), as well as to the depth of student thinking (Jenson, 2011). There is also evidence to suggest that strategies employed by students to self-regulate their learning (Barnard-Brak, Paton, \& Lan, 2010), as well as the frequency with which they use those strategies, may vary (Dörrenbächer \& Perels, 2016).

A self-regulated student can monitor his or her learning and identify and implement strategies to succeed (Miller, 2015). Self-regulation learning strategies are important in traditional classrooms (Cleary \& Zimmerman, 2012; Inan, Yukselturk, Kurucay, \& Flores, 2017) and in blended learning contexts (Zhu, Au, \& Yates, 2016), and they are particularly critical in online learning environments (Azevedo \& Cromley, 2004; Inan et al., 2017; Yukselturk \& Bulut, 2007). The autonomous nature of online learning and the fact that instructors may have difficulty facilitating learning activities due to the lack of face-to-face interaction means that students need to be self-regulated learners to succeed (Artino \& Stephens, 2009; Barnard, Lan, To, Paton, \& Lai, 2009; Broadbent, 2017). Also, previous research has highlighted that self-regulated learning strategies are more frequent in online settings (Kuo, Walker, Schroder, \& Belland, 2014).

A set of subscales has been described in the literature which measures self-regulation learning and is used to guide development of questionnaire items (self-regulation learning questionnaires). These subscales have been extensively reviewed (Barnard, Lan, To, Paton, \& Lai, 2009; Nota, Soresi, \& Zimmerman, 2004; Pintrich \& Zusho, 2007; Schunk \& Zimmerman, 1997; Zimmerman \& Schunk, 2011) (Table 1). 
Table 1

Self-regulation subscales for learning

\begin{tabular}{|c|c|}
\hline Subscale & Description \\
\hline Environment structuring (ES) & $\begin{array}{l}\text { Learners need to structure their physical learning environment } \\
\text { (e.g., home, library, or elsewhere) to avoid disruptions } \\
\text { (Zimmerman, 1995). }\end{array}$ \\
\hline Goal setting (GS) & $\begin{array}{l}\text { Learners need to set their goals and orientation towards their } \\
\text { studies (Pintrich, Smith, Garcia, \& McKeachie, 1991). }\end{array}$ \\
\hline Time management (TM) & $\begin{array}{l}\text { Refers to effective time allocation when completing a task or } \\
\text { activity (Dabbagh \& Kitsantas, 2004). Learners need to } \\
\text { schedule, plan, and manage their study time (Chen, 2002). }\end{array}$ \\
\hline Task strategies (TS) & $\begin{array}{l}\text { Describes student approaches to learning tasks, such as note- } \\
\text { taking and preparation of questions to ask educators } \\
\text { (Zimmerman, 2002). }\end{array}$ \\
\hline Help-seeking (HS) & $\begin{array}{l}\text { Considered a social component of self-regulation (Hodges, } \\
2005 \text { ), this is defined as the learner's ability to seek academic } \\
\text { help (e.g., from peers, instructors) in an adaptive manner and to } \\
\text { promote their learning (Lynch \& Dembo, 2004). }\end{array}$ \\
\hline Self-evaluation (SE) & $\begin{array}{l}\text { Defined as the learner's capacity to monitor and evaluate } \\
\text { personal effectiveness concerning specific learning tasks } \\
\text { (Winne \& Hadwin, 1998). }\end{array}$ \\
\hline Self-consequences & $\begin{array}{l}\text { Refers to what learners regard as reward or punishment for } \\
\text { success or failure in a learning task (Nota et al., 2004). }\end{array}$ \\
\hline
\end{tabular}

Identifying self-regulation learning skills is crucial. They are learnable skills, and educators can help students to acquire and master them (Azevedo \& Cromley, 2004; Dabbagh \& Kitsantas, 2004). For LGDM assignments, students need to research their topics (storyboarding) and review online training materials about producing digital media. As such, we propose that there is a component of self-regulated learning relating to searching for information and a component relating to learning digital media production. In LGDM assignments, students must develop a high level of autonomy to complete the task successfully. Only a few studies on LGDM have reported providing formal student training (face-to-face or blended) in digital media production (Reyna, Horgan, et al., 2017; Reyna et al., 2016). In many the cases, students needed to seek digital media production training materials online (e.g., YouTube.com, Lynda.com). When students plan their LGDM assessment tasks with their groups and engage in planning, scheduling meetings, seeking help, developing task strategies, and so forth, they will need to use self-regulation learning strategies. Digital media production has been characterised as time-consuming, iterative, and resourceintensive (Musburger \& Kindem, 2012; Sørensen \& Levinsen, 2014) and it requires self-regulation skills to accomplish. We posit that LGDM assignments require a high degree of student self-regulation learning skills. Therefore, this research uses the self-regulation model linked to the LGDM implementation framework to guide the evaluation of LGDM assignments.

\section{Materials and methods}

\section{Theoretical framework}

The LGDM framework was used to design and implement the assignment (Reyna \& Meier, 2018). This framework has eight components to guide the implementation of digital media assignments in the classroom (see Figure 1). The framework was refined and validated in previous studies in scientific disciplines such as pharmacology (Reyna et al., 2016) and geological processes (Reyna, Horgan et al., 2017). Mapping of the elements of the LGDM framework against self-regulation subscales and other constructs was done before the design of the questionnaire (Table 2). As the LGDM framework informed the assignment design, implementation, and evaluation, the mapping was necessary to link the different elements of the framework. 


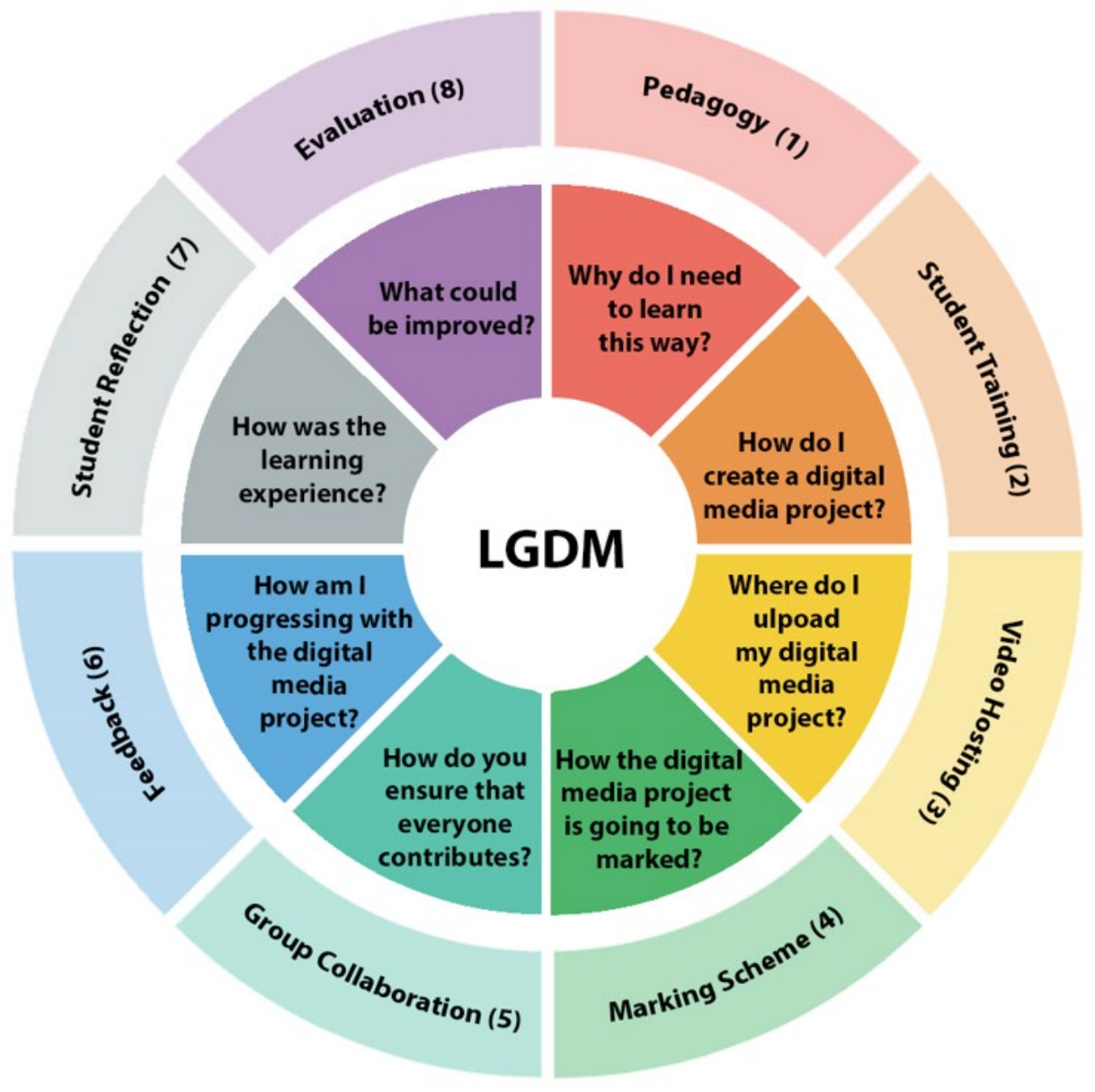

Figure 1. The LGDM implementation framework

Table 2

The LGDM framework mapped against self-regulation subscales and additional constructs

\begin{tabular}{ll}
\hline Element & Subscales \\
\hline Pedagogy & Digital media for learning and career** \\
Student training & Task strategies* \\
Video hosting and distribution & Assignment ownership** \\
Marking scheme & Assignment motivation** \\
Group work & Goal setting* \\
& Environment structuring* \\
& Time management* \\
Feedback & Help-seeking* \\
Reflection & Self-evaluation* \\
Evaluation & Self-evaluation* \\
\hline Note $*$ Indicates self-regulation
\end{tabular}

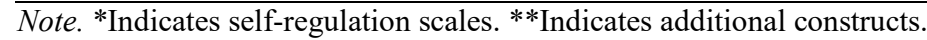

The rationale for the inclusion of additional constructs in the questionnaire was informed by research in the field of self-regulation and motivation in LGDM assignments. According to the literature, motivation is the sine qua non of self-regulation processes (Dunnigan, 2018; Pintrich et al., 1991; Zimmerman, 1989; Zimmerman \& Schunk, 2011). For instance, self-efficacy, attribution to failure, task value, and anxiety affect self-regulation strategies (Bandura, 1986; Elliot \& Harackiewicz, 1994; Pintrich \& Zusho, 2007; Zimmerman, 2000). Studies have suggested that attitudes determine how students perceive situations, how they feel about them, and how they behave in those situations (Ajzen, 1996; Fazio \& Roskos-Ewoldsen, 2005). In the current literature on LGDM assignments, it appears that there are no validated surveys available to measure student attitudes towards LGDM for learning and career. Student attitudes towards 
digital media for learning and career were considered in this study to be an essential construct to establish the relationship of motivation with self-regulation processes.

The authors postulated a link between assignment ownership, video hosting, and the presentation component. Research in the field of LGDM with pre-service teachers suggests that students are motivated to produce their digital media projects by the sense of having an audience (Kearney, 2013; Kearney \& Schuck, 2005). Students work harder to achieve a better outcome in digital media projects when they know, for instance, that the YouTube community will see their content (Hobbs, 2017; Van Dijck, 2009a). This sense of an audience boosts student agency and satisfaction in contributing to the learning experience of other students around the world (Hoban et al., 2015; Hobbs, 2017). A possible relationship between assignment motivation and the marking scheme emerged from the previous research. If the student's perception of task value is low, it will affect the effort they are willing to put into their project (Reyna \& Meier, 2018) and could therefore affect their ability to self-regulate.

It is common in the literature on self-regulation to link survey questions with motivational features such as self-efficacy or task value. For instance, a study conducted by Wang, Shannon, and Ross (2013) measured personal characteristics, technology self-efficacy, and self-regulation beliefs to understand academic outcomes and satisfaction levels. Similar studies using mixed scales are available in the literature. For instance, Agustiani, Cahyad, and Musa (2016) studied how self-regulation can influence academic outcomes in online courses using a mixed scale including self-regulation, motivation, task value, and selfefficacy. Lynch and Dembo (2004) conducted a study to investigate self-regulation as a predictor of academic success in a blended learning course using self-regulation subscales, verbal ability, and selfefficacy for learning and performance. Another study, conducted by McClain (2015), used a mixed scale including self-regulated learning levels and a self-monitoring instrument to gauge academic achievement in an online post-secondary developmental mathematics course.

\section{The self-regulation learning questionnaire for LGDM assignments}

This questionnaire is part of a framework to evaluate the effectiveness of the learning experience when using LGDM assignments in the classroom (Reyna, Hanham, \& Meier, 2018b). The framework was developed using a mixed-methods approach (Tashakkori \& Teddlie, 2010) and has quantitative (surveys, marks, learning management system (LMS) logs) and qualitative components (open-ended questions, interviews, focus groups). Part of the quantitative section of the framework uses a questionnaire to measure self-regulated learning and additional constructs such as student attitudes towards digital media for learning, digital media for careers, and assignment motivation and ownership (see Table 2).

Self-regulation is highly context-dependent (Zimmerman, 1998; Zimmerman \& Tsikalas, 2005), and research has found that in traditional face-to-face settings learners use different self-regulation strategies than when they are operating in online settings (Broadbent, 2017). Although comparisons of self-regulation in traditional versus online settings are scarce in the literature (Barnard-Brak et al., 2010), one of the reasons for the difference in self-regulation from traditional settings could be the social context offering opportunities to support self-regulation (Zimmerman, 2000). For instance, effective feedback from instructors and peers in the classroom could support self-efficacy and help learners deal with feelings like anxiety and fear (Hadwin, Oshige, Gress, \& Winne, 2010). These motivational factors are the sine qua non of self-regulation processes (Pintrich \& Zusho, 2007). In contrast, autonomy is a characteristic of online environments, and self-regulation learning strategies have been highlighted as a crucial component of student learning and achievement online (Barak, Hussein-Farraj, \& Dori, 2016; Dabbagh \& Kitsantas, 2004; Kocdar, Karadeniz, Bozkurt, \& Buyuk, 2018). In online settings, learners need to be more independent and self-directed than in traditional settings. Online activities are open regarding time, pace, and content, which means that self-regulation learning skills such as time management are required (Barak et al., 2016; Barnard et al., 2009; Bergamin, Ziska, Werlen, \& Siegenthaler, 2012; Garrison, 2000; Kauffman, 2004). Students lacking self-regulation learning skills may misconceive the autonomy of the learning environment and underperform (Barnard et al., 2009). On the other hand, online learning environments could support self-regulation learning skills by providing opportunities for self-monitoring, peer interaction, and mastering learning (Barnard et al., 2009; Cho \& Heron, 2015). For instance, research has found that online students use self-regulation strategies more often than blended students, except for peer-learning and help-seeking (Broadbent, 2017). However, self-regulation in online settings has not received the same attention as self-regulation in traditional face-to-face settings (Barnard, Paton, \& Lan, 
2008). This research gap presented challenges when developing the self-regulation questionnaire for the present study.

Reviewing the literature on self-regulation learning scales for traditional modes of delivery (Brown, Miller, \& Lawendowski, 1999; Pintrich et al., 1991; Weinstein \& Palmer, 2002), we found the scales to be unsuitable for online learning, as also reported recently by Kocdar et al. (2018). A validated instrument such as the motivated strategies for learning questionnaire (Pintrich, Smith, Garcia, \& McKeachie, 1993), which measures self-regulation in traditional learning environments, may be invalid in online settings, as argued by Barnard et al. (2009). Due to the differences reported between self-regulation in traditional faceto-face learning and in online learning, the questionnaire subscales and items on self-regulation learning for the current study were adapted from the online self-regulation questionnaire (Barnard et al., 2009; Barnard-Brak et al., 2010) (see Appendix A). Items from this survey were chosen and adapted because of their generality and internal reliability scores. Due to the diversity of the survey items, the statements were rewritten to replace "online learning" with "digital media assignment" to reflect the task that the students would undertake during the semester (i.e., "I allocate extra time for my online courses" was changed to "I allocate extra time for my digital media assignment"). Questionnaire items were developed using a fourpoint Likert scale - 1 strongly disagree, 2 disagree, 3 agree, and 4 strongly agree. The authors did not include a middle point (neutral), to avoid indecisive data (Busch, 1993). The objective was to study selfregulation and neutral responses were of limited utility. A similar approach was used in a recent study on developing self-regulation in self-paced open and distance learning environments that used a five-point Likert scale including slightly agree as a middle point (Kocdar et al., 2018). Appendix B presents the subscales and survey items for self-regulation learning and the additional constructs.

\section{Participants}

Our research was conducted at a metropolitan university in Sydney, Australia, during Semester 1, 2017. Science students $(n=1656)$ from seven subjects which had implemented LGDM assignments in years 1 to 3 were asked to complete a questionnaire (Table 3) at three times during the semester: T1 (Week 2); T2 (Week 6); and T3 (Week 10). Three datapoints were used to ensure student self-regulation learning strategies could be tracked across the semester.

Table 3

Science subject cohorts which implemented LGDM assignments in Semester 1, 2017, and participated in the questionnaire validation study

\begin{tabular}{lcccc}
\hline Subject & Year & $\begin{array}{c}\text { LGDM assignment } \\
\text { weight (\%) }\end{array}$ & Delivery mode & $\boldsymbol{N}$ \\
\hline Health and Homeostasis 1 & 1 & 20 & $\mathrm{O}$ & 697 \\
Investigation of Human remains & 2 & 30 & $\mathrm{~B}$ & 78 \\
Geological processes & 2 & 20 & $\mathrm{~B}$ & 103 \\
Pharmacology 1 & 3 & 15 & $\mathrm{~B}$ & 295 \\
Neuroscience & 3 & 30 & $\mathrm{~B}$ & 323 \\
Molecular Nanotechnology & 3 & 10 & $\mathrm{O}$ & 50 \\
Medical imaging & 3 & 30 & $\mathrm{~B}$ & 110 \\
\hline Total & & & $\mathbf{1 6 5 6}$ \\
\hline
\end{tabular}

Note. $\mathrm{O}=$ Online delivery, $\mathrm{B}=$ Blended delivery.

Students were sent a link via email and asked to participate in the survey on a voluntary basis in Weeks 2 , 6 , and 10. The questionnaire was designed inside the LMS, and participant data were identified to ascertain patterns of students' self-regulation learning. This research had full ethics approval (ETH16-1060). Data were gathered from the Grade Centre as comma-separated values (CSV) for each point of time, cleaned, and processed into one file containing entries for only those students who responded to all of T1, T2, and T3. 


\section{LGDM task design}

The LGDM assignment task design followed a systematic approach. The following frameworks were used to inform the creation of the assessment task:

- $\quad$ the digital media literacies framework (Reyna et al., 2018c);

- $\quad$ the taxonomy of digital media types (Reyna, Hanham, \& Meier, 2017);

- $\quad$ the digital media principles framework (Reyna, Hanham, \& Meier, 2018a); and

- $\quad$ the LGDM implementation framework (Reyna \& Meier, 2018).

The digital media literacies framework was used to plan, design, and implement face-to-face and online student training. This model has three domains: conceptual, functional, and audiovisual. Students received training on storyboarding for digital media (conceptual), essential use of video editing software (functional) and, finally, audiovisual aspects of producing effective digital media. The taxonomy of digital media types (Reyna et al., 2017) was used to explain to students the skills required for the digital media type they chose for their assignments. The digital media principles framework (Reyna et al., 2018a) guided the audiovisual training (layout design, colour theory, typography, use of images, and basic video techniques). The LGDM implementation framework (Reyna \& Meier, 2018) guided academics and students to understand the assignment workflow. The weightings of the tasks ranged from $10 \%$ to $30 \%$. The delivery mode of the digital media training was blended for five subjects and online for two subjects (Table 3 ).

\section{Exploratory and confirmatory factor analysis}

Because the self-regulation questionnaire was adapted from a previous study (Barnard et al., 2009) and additional constructs were added, there was a need to validate the constructs and questionnaire items. For this purpose, a multivariate statistical approach, exploratory and confirmatory factor analysis, was used (Williams, Onsman, \& Brown, 2010). This statistical approach is used to interpret self-reporting questionnaires in educational psychology and health interventions (Thompson, 2004). Exploratory factor analysis (EFA) is used when the researcher has no prediction of the number of constructs to be measured (Costello \& Osborne, 2005). The primary objective is to reduce many variables to a smaller set of factors. This process tests whether there is a relationship between variables and latent constructs (O'Rourke, Psych, \& Hatcher, 2013). Confirmatory factor analysis (CFA) is used by researchers to propose a priori factor structures based on theory and preliminary analyses like EFAs, and it provides validity evidence for the scales used in the questionnaire. Both EFA and CFA help to refine a proposed theory (Harrington, 2009).

\section{Questionnaire validation}

Data collected during the semester for T1 (Week 2), T2 (Week 6), and T3 (Week 10) were used to run EFAs and CFAs to identify factor structures and assess the reliability of the constructs. The sample was split in half as follows:

- $\quad$ split data in half for T1;

- $\quad$ split data in half for T2 + T3;

- $\quad$ run EFA for the first half of T1 data;

- $\quad$ run EFA for the first half of T2 + T3 data; (e) run CFA for the second half of T1 data; and

- $\quad$ run CFA for the second half of $\mathrm{T} 2+\mathrm{T} 3$ data.

The reason that the data were analysed as described was that T2 and T3 contained co-regulation questions for a second study which are beyond the scope of this paper (Figure 2). Therefore, it was necessary to check if the same results would be generated if co-regulation factors were included. The results were similar, so the same questions were combined to form factors. 
Time

Survey components

Factor Analysis
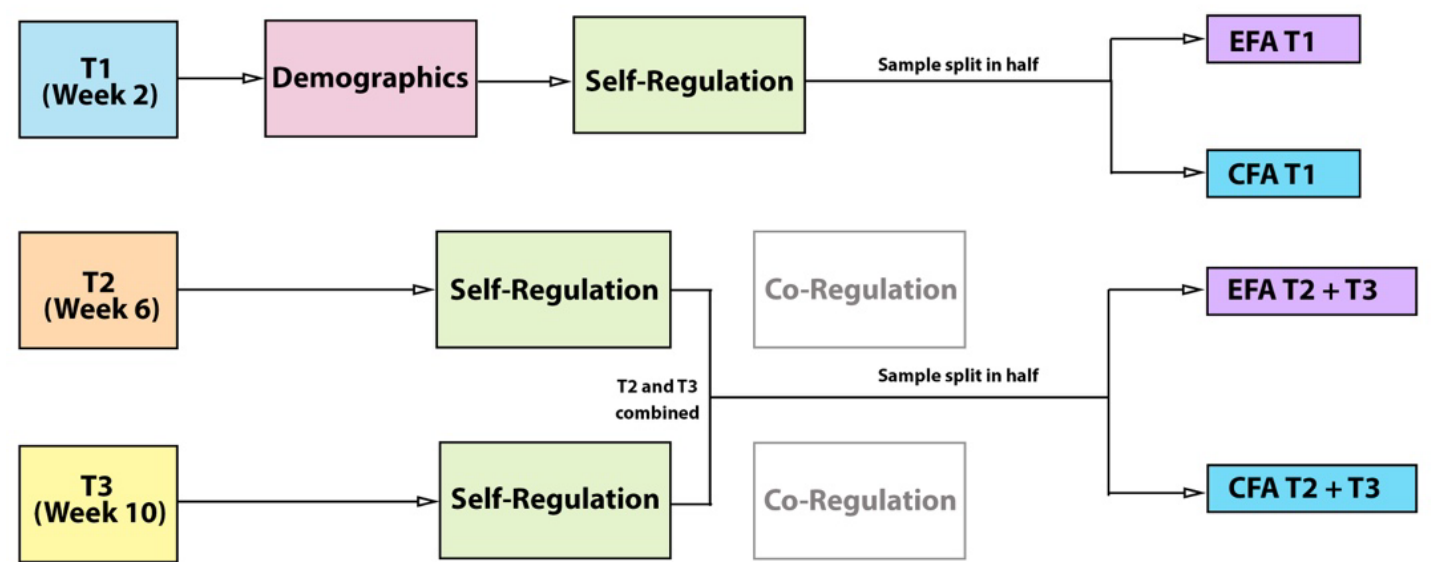

Figure 2. Sample split for EFA and CFA. EFA T1 was similar to EFA T2 + T3, and CFA T1 was similar to CFA T2 + T3 $(n=341)$.

The data were analysed using SPSS (version 24.0). Factors were extracted using principal axis factoring (Henson \& Roberts, 2006). The criteria to determine the number of factors to extract were Kaiser's criteria (eigenvalues $>1$ rule) (Kaiser, 1960), the scree test (Cattell, 1966), the cumulative percentage of variance extracted (Horn, 1965), and most importantly, theoretical interpretability (Williams et al., 2010). The rotational method varimax was used to maximise high item loadings and minimise low item loadings to produce a simplified solution (Thompson, 2004). Parameter estimates (i.e., factor loadings, modification indices, error variances) and a combination of fit indices (e.g., root mean square error of approximation [RMSEA], CFI) were examined when assessing confirmatory factor (measurement) models.

\section{Results}

\section{Questionnaire completions}

Twenty percent of participants were male and $80 \%$ were female. Regarding the ages of the participants, $91 \%$ were between 19 and 29,6\% were between 30 and 39, and 3\% were 40 and over. Fifty-three percent of the students were native English speakers and 47\% were ESL students. For T1, T2, and T3 surveys, 955 , 697, and 626 students responded, respectively. There was a decrease in responses towards the end of the semester. This pattern was expected as students were finalising assignments and preparing for exams. For the factor analyses, data were cleaned and only included students who completed all of T1, T2, and T3, which ensured data consistency. Table 4 presents completion rates of $\mathrm{T} 1+\mathrm{T} 2+\mathrm{T} 3$ for each subject.

Table 4

Science subject cohort response rates for T1 +T2 + T3 questionnaires in Semester 1, 2017

\begin{tabular}{lcccc}
\hline Subject & Year & $\boldsymbol{N}$ & Responses & \% \\
\hline Health and Homeostasis 1 & 1 & 697 & 199 & 29 \\
Investigation of Human Remains & 2 & 78 & 48 & 62 \\
Geological Processes & 2 & 103 & 17 & 17 \\
Pharmacology 1 & 3 & 295 & 22 & 8 \\
Neuroscience & 3 & 323 & 30 & 9 \\
Molecular Nanotechnology & 3 & 50 & 13 & 26 \\
Medical Imaging & 3 & 110 & 12 & 11 \\
\hline Total & & $\mathbf{1 6 5 6}$ & $\mathbf{3 4 1}$ & \\
\hline
\end{tabular}

\section{EFA}

The Kaiser-Meyer-Olkin (KMO) measure and Bartlett's test of sphericity were used to determine if the data were suitable for factor analysis. Bartlett's test demonstrated significance, as the KMO was higher than 0.50 (Table 5). 
Table 5

Assessing the suitability of data for EFA

\begin{tabular}{lll}
\hline KMO of sampling adequacy & & .906 \\
\hline Bartlett's test of sphericity & Approx. Chi-square & 8343.152 \\
& df & 780 \\
& Sig. & .000 \\
\hline
\end{tabular}

As seen in Table 5, the KMO coefficient and Bartlett's test value for the 40 items passed the reliability test, at 0.906 and 0.000 respectively. The KMO coefficient showed that the sample size was close to perfect, and Bartlett's test indicated that the data set was suitable for EFA. Principal axis factoring was the method used for factor extraction. The scree test suggested taking ten factors, the second elbow on the plot. Looking at the total variance extracted by each factor, the ten factors made sense (Figure 3). Figure 3 shows that the break point happened after the tenth factor, when the factor eigenvalue dropped below 1 .

\section{Scree Plot}

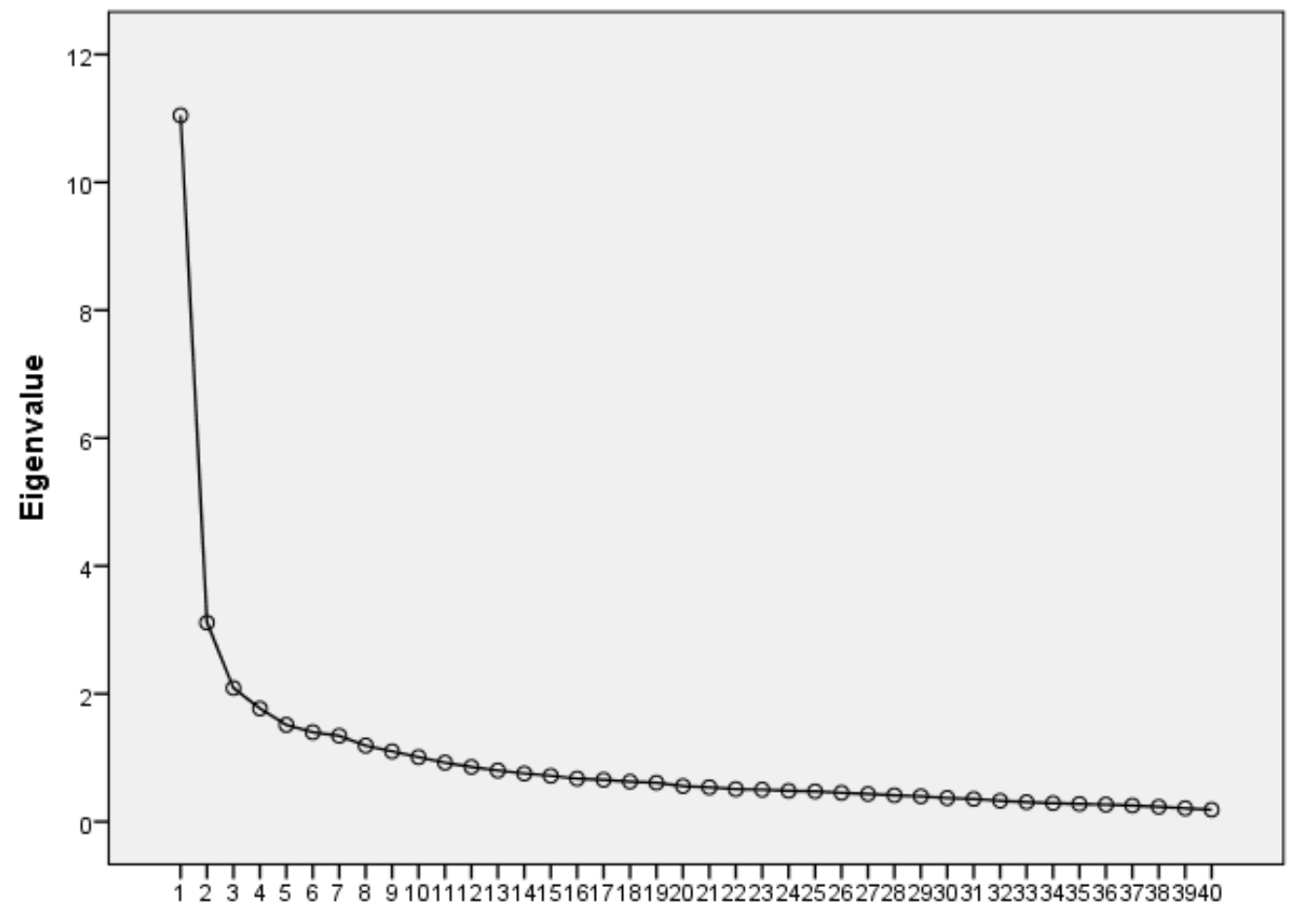

Figure 3. Factor eigenvalue by factor number

\section{Factor Number}

Table 6 shows that a ten-factorial structure explained $63.929 \%$ of the total variance. The ten factors are presented in Table 7.

Table 6

Factor eigenvalues and variances

\begin{tabular}{lccc}
\hline Component & Total & $\begin{array}{c}\text { Initial eigenvalues } \\
\text { \%o of variance }\end{array}$ & Cumulative\% \\
\hline 1 & 11.047 & 27.618 & 27.618 \\
2 & 3.112 & 7.780 & 35.398 \\
3 & 2.089 & 5.223 & 40.621 \\
4 & 1.771 & 4.428 & 45.049 \\
5 & 1.513 & 3.783 & 48.832 \\
6 & 1.399 & 3.496 & 52.328 \\
7 & 1.342 & 3.356 & 55.684 \\
8 & 1.190 & 2.974 & 58.658 \\
9 & 1.099 & 2.747 & 61.405 \\
10 & 1.010 & 2.524 & 63.929 \\
\hline
\end{tabular}


To make the axes fit the data better, varimax rotation was used. Factors whose questions exactly matched the previous set groupings were labelled with their original names, but those whose questions were a mixture of groupings were given a different name. For example, help-seeking generated two different factors: help-seeking from people and help-seeking from the Internet. The summary is presented in Table 7.

Table 7

Factors extracted by EFA for T1

\begin{tabular}{lll}
\hline Factor & Factor name & Description \\
\hline 1 & DMC & Digital media for career \\
2 & HSP* & Help-seeking from people* \\
3 & ES* & Environment structuring* \\
4 & GS $^{*}$ & Goal setting* \\
5 & TM* $^{*}$ & Time management* \\
6 & DML & Digital media for learning \\
7 & TS* & Task strategies* \\
8 & AO & Assignment ownership \\
9 & HSI* & Help-seeking from the Internet* \\
10 & AM & Assignment motivation \\
\hline Note. $*$ Denotes self-regulation items. &
\end{tabular}

Of the 40 items, eight had very small loadings for all factors (five self-regulation items and three items in other constructs), so they were not included in any factor. The questions with no grouping are presented in Table 8.

Table 8

Items with small loadings on all factors that were discarded from the data

\begin{tabular}{ll}
\hline No. & Item \\
\hline 23 & I set long-term goals (e.g., across semester) when preparing my digital media assignment.* \\
40 & I reflect on what I have learnt on my assignment.* \\
28 & I allocate extra time for my digital media assignment.* \\
19 & I visit additional resources online about digital media.* \\
15 & I would like to produce a digital media assignment that I can be proud of. \\
12 & I am driven by learning rather than marks. \\
9 & I am driven by marks. \\
37 & I ask myself questions about the assignment material when preparing the digital media \\
& assignment.* \\
\hline Note. ${ }^{*}$ Denotes self-regulation items.
\end{tabular}

For the model fit measures, the minimum discrepancy/degrees of freedom (CMIN/DF) ratio was low at 1.875 , which is a good value, but the $p$ value was significant, indicating a poor fit (Table 9). However, the sample size is large, so the probability that any fit would have a non-significant $p$ value is very low. The comparative fit index (CFI) is acceptable at 0.945, as is the parsimonious comparative fit index (PCFI) at 0.798 (Table 10). The PCLOSE is acceptable at 0.995 , as is the RMSEA at 0.043 (Table 11). The values were in the range of the standard fit criteria (Schermelleh-Engel, Moosbrugger, \& Müller, 2003) (Table 12). Therefore, the model fit is acceptable.

Table 9

Model fit measures (CMIN)

\begin{tabular}{lccccc}
\hline Model & NPAR & CMIN & DF & P & CMIN/DF \\
\hline Default model & 141 & 785.670 & 419 & .000 & 1.875 \\
Saturated model & 560 & .000 & 0 & & \\
Independence model & 64 & 7102.771 & 496 & .000 & 14.320 \\
\hline
\end{tabular}


Table 10

Baseline comparisons

\begin{tabular}{lrrrrr}
\hline Model & $\begin{array}{r}\text { NFI } \\
\text { Delta1 }\end{array}$ & $\begin{array}{r}\text { RFI } \\
\text { rho1 }\end{array}$ & $\begin{array}{r}\text { IFI } \\
\text { Delta2 }\end{array}$ & $\begin{array}{r}\text { TLI } \\
\text { rho2 }\end{array}$ & CFI \\
\hline Default model & .889 & .869 & .945 & .934 & .945 \\
Saturated model & 1.000 & & 1.000 & 1.000 \\
Independence model & .000 & .000 & .000 & .000 & .000 \\
\hline
\end{tabular}

Table 11

RMSEA

\begin{tabular}{lrrrr}
\hline Model & RMSEA & LO 90 & HI 90 & PCLOSE \\
\hline Default model & .043 & .038 & .047 & .995 \\
Independence model & .167 & .164 & .171 & .000 \\
\hline
\end{tabular}

Table 12

Standard fit criteria for CFA

\begin{tabular}{lll}
\hline Measures & The best values & Acceptable values \\
\hline RMSEA & From .00 to .05 & From .05 to .08 \\
SRMR & From .00 to .05 & From .05 to .10 \\
GFI & From .95 to 1.00 & From .90 to .95 \\
AGFI & From .90 to 1.00 & From .85 to .90 \\
CFI & From .95 to 1.00 & From .90 to .95 \\
RFI & From .90 to 1.00 & From .85 to .90 \\
\hline
\end{tabular}

EFA was determined, applied, measured and assessed separately for T1 and T2 + T3, because in T1 students were not asked the co-regulation questions that were part of another study. This was done to verify if the grouping of questions under self-regulation factors would differ when co-regulation questions were included. The self-regulation factors and additional constructs remained the same for EFA conducted on $\mathrm{T} 1$ and on T2 + T3. Only data which includes T1 has been included.

\section{CFA}

Appendix $\mathrm{C}$ shows the loading per factor for the self-regulation subscales and additional constructs. The CMIN/DF ratio was relatively low at 2.525, but the $p$ value was significant, indicating a poor fit (Table 13). However, as above, the large sample size minimises the chances of getting a non-significant $p$ value. The CFI and the PCFI values are within the threshold at 0.934 and 0.805 , respectively (Table 14). The PCLOSE is acceptable at $0.851(>0.5)$, as is the RMSEA at $0.049(<0.05)$ (Table 15). These values were in the range of the standard fit criteria (Schermelleh-Engel et al., 2003) (Table 12). Thus, it can be concluded that overall the model fit is acceptable. For T2 + T3, CFA gave similar results.

Table 13

Model fit measures (CMIN)

\begin{tabular}{llllll}
\hline Model & NPAR & CMIN & DF & P & CMIN/DF \\
\hline Default model & 166 & 1449.461 & 574 & .000 & 2.525 \\
Saturated model & 740 & .000 & 0 & & \\
Independence model & 74 & 13949.244 & 666 & .000 & 20.945 \\
\hline
\end{tabular}

Table 14

Baseline comparisons

\begin{tabular}{llllll}
\hline Model & $\begin{array}{l}\text { NFI } \\
\text { Delta1 }\end{array}$ & $\begin{array}{l}\text { RFI } \\
\text { rho1 }\end{array}$ & $\begin{array}{l}\text { IFI } \\
\text { Delta2 }\end{array}$ & $\begin{array}{l}\text { TLI } \\
\text { rho2 }\end{array}$ & CFI \\
\hline Default model & .896 & .879 & .935 & .924 & .934 \\
Saturated model & 1.000 & & 1.000 & & 1.000 \\
Independence model & .000 & .000 & .000 & .000 & .000 \\
\hline
\end{tabular}




\begin{tabular}{lllll}
\hline Model & RMSEA & LO 90 & HI 90 & PCLOSE \\
\hline Default model & .048 & .045 & .051 & .851 \\
Independence model & .174 & .171 & .176 & .000 \\
\hline
\end{tabular}

\section{Discussion}

This research paper is the first attempt to develop and validate a self-regulation learning questionnaire to be used in LGDM assignments. A ten-factor structure was identified by EFA. Six factors corresponded to self-regulation learning (goal setting, environment structuring, time management, task strategies, helpseeking from people, and help-seeking from the Internet). Notably, help-seeking generated two factors not previously reported in the literature (help-seeking from people and help-seeking from the Internet). Other studies have identified additional self-regulation learning factors, for example, self-study strategies (Kocdar et al., 2018). Following CFA, comparison of the values obtained for RMSEA, SRMR, CFI, and RFI against the best values/acceptable values (Schermelleh-Engel et al., 2003) confirmed the six-factor structure of the self-regulation learning skills scale and additional constructs. The remaining four factors identified were student attitudes towards LGDM assignments (digital media for learning, digital media for career) and assignment motivation and ownership. These additional factors were included in the scale to reflect that motivation is the sine qua non of self-regulation processes (Dunnigan, 2018; Pintrich et al., 1991; Zimmerman, 1989; Zimmerman \& Schunk, 2011).

Task strategies describes student approaches to learning tasks, such as note-taking, and preparation of questions to ask educators (Zimmerman, 2002). In the context of digital media, task strategies are crucial because students will need to engage with digital media resources inside the LMS and master relevant software to produce their assignments. Previous research in LGDM suggests that students feel overwhelmed by the task when they don't receive any support from educators (Coulson \& Frawley, 2017; Pearce, 2014; Pearce \& Vanderlelie, 2016). For task strategies, one of the self-regulation learning subscales, three out of four items were validated. The item not validated was "I visit additional resources online about digital media." This was possibly because digital media resources were developed and provided inside the LMS, and so students did not need to look for additional material. The original validated survey (Barnard et al., 2009) used to build the section which included this subscale also included two questions that could not be adapted to the LGDM task: "I prepare my questions before joining the chat room and discussion" and "I work extra problems in my online courses in addition to the assigned ones to master the course content." Nevertheless, the number of items for TS is in the range suggested by previous studies ( 2 or 3 items per factor), so it can give a meaningful interpretation of the construct (Henson \& Roberts, 2006; Isaac \& Michael, 1995).

Students need to set their goals and orientation towards their studies (Pintrich et al., 1991). For goal setting, three items out of four were validated. The item that was not validated was "I set long-term goals (e.g., across semester) when preparing my digital media assignment", which is probably due to the LGDM assignment being a single semester task. The meaning of "long-term" can be a year or more, and the subject only lasted 12 weeks. Students may have responded to the item inconsistently, and this may explain why this item failed to be validated. For environment structuring, all four items were validated by factor analysis. In the case of time management, three out of four items were validated. The item "I allocate extra time for my digital media assignment" was not validated.

Interestingly, after EFA items for help-seeking (items 32-36) and self-evaluation (items 37-40), formed two different factors that were labelled as help-seeking from people (items 32-34 and items 38 \& 39) and help-seeking from the Internet (items $35 \& 36$ ). Two items under self-evaluation were not validated - "I ask myself questions about the assignment material when preparing the digital media assignment" and "I reflect on what I have learnt on my assignment". The self-evaluation factor was thus deleted from the questionnaire (see Table 3). This sort of result is expected when validating questionnaires using factor analysis, as not all measurement items capture the underlying constructs effectively or consistently (Williams et al., 2010). Moreover, a recent study found that self-evaluation was not a significant factor for explaining student achievement and satisfaction in an entirely online course (Inan et al., 2017). Contrarily, 
other authors have described self-evaluation as an essential skill for students to be successful in online learning courses (Barnard et al., 2008; Dabbagh \& Kitsantas, 2004).

As emphasised previously, self-regulation is highly context-dependent (Schunk \& Zimmerman, 2011). In the present study, all students were taught in blended mode, but the training for the LGDM assignment was delivered entirely online for two cohorts $(n=212)$ and in blended mode for five cohorts $(n=129)$. This approach could distort validation results. A recent study has described how online and blended learners varied in their self-regulation strategies. Online learners use self-regulation learning strategies more often than blended learners, except for peer learning and help-seeking, which are employed more often by blended learning students (Broadbent, 2017).

The digital media for learning and digital media for career items were validated by EFA and CFA. This means that these items are representative for evaluating student attitudes towards LGDM for their career and attitudes towards technology for learning subject content. Attitudes determine how students perceive situations, how they feel about them, and how they behave (Ajzen, 1996; Fazio \& Roskos-Ewoldsen, 2005). Understanding these additional constructs could help to establish their relationship with self-regulation processes.

For assignment motivation, factor analysis only validated two items out of four. The items not validated were "I am driven by marks" and "I am driven by learning rather than marks." Assignment motivation can also affect self-regulation processes. In the psychology literature, task value refers to perceptions of interest, usefulness, importance, and costs of a task (Meece, Blumenfeld, \& Hoyle, 1988). Students who attach a high value to the task are likely to use deeper cognitive and metacognitive strategies for learning (Pintrich, 2004). Previous research suggests that if the LGDM task has a low weighting in total marks $(10 \%-15 \%$ of the total mark), students are likely to apply less effort to the assignment (Reyna \& Meier, 2018). Due to the often time-consuming, iterative, and laborious nature of digital media production (Musburger \& Kindem, 2012), allocating the appropriate proportion of total marks to the task is of crucial importance to motivate students to successfully complete the assignment. A relatively high weighting for the assessment task ( $25 \%-30 \%$ of the total mark) could create a positive environment regarding expectations, task value, and beliefs that will affect subsequent behaviour (Wigfield \& Eccles, 2000). Furthermore, the taxonomy of digital media types (Reyna et al., 2017) could be a valuable tool for educators new to digital media assignments. This model could help them to decide on assignment weighting according to digital media type, avoiding unfairness and improving student motivation by increasing task value.

For assignment ownership, factor analysis validated two out of three items. The item not validated was "I would like to produce a digital media assignment that I can be proud of it." The number of items under each of these factors is in the range suggested by previous studies ( 2 or 3 items per factor), so these items can give a meaningful interpretation, similarly to task strategies, discussed above. It has been reported in the literature that the sense of an audience (e.g., the LGDM assignment is uploaded onto YouTube) can motivate students to put greater effort into their projects (Kearney, Pressick-Kilborn, \& Maher, 2012; Kearney \& Schuck, 2005). However, there may also be other drivers of motivation in LGDM assignments, such as the need for self-expression and creativity (Van Dijck, 2009; Van Dijk \& Lazonder, 2016).

\section{Conclusion}

Preliminary validation of questionnaire items indicated that our model is fit for evaluating self-regulation learning subscales such as goal setting, environment structuring, time management, task strategies, helpseeking from people, and help-seeking from the Internet in LGDM assignments. Items from additional constructs such as attitude towards digital media for learning and career, assignment motivation, and assignment ownership items were also validated. The present study is one of the first to develop and validate a self-regulation learning questionnaire for LGDM assignments. This validated questionnaire will help educators develop strategies to enable students to acquire or improve self-regulation learning in LGDM assignments. 


\section{Implications of the study}

There are some implications which flow from the findings of this study. Based on the data, students employed a number of self-regulation strategies, specifically environmental structuring, goal setting, time management, help-seeking from people, help-seeking from the Internet, and also task strategies related to note-taking and accessing digital resources within the LMS. The verification of these strategies in the context of student experience of LDGM has practical implications. Environmental structuring (Kocdar et al., 2018; Su, Zheng, Liang, \& Tsai, 2018; Zimmerman, 2008) has been identified in a range of contexts as an important self-regulation strategy. In this study, environmental structuring focused on students choosing times and locations in which to work on their digital media assignments. The exercise of personal control (Lee \& Brand, 2010) is an important mechanism in environmental structuring. Educators can provide students with some direction on how to organise and structure their environments to minimise distractions. This may include advice about putting mobile phones on silent, locating distraction-free learning spaces, and identifying times during the week when distractions are likely to be minimal. Educators can also assist students with goal setting. For example, throughout the time period for an LDGM assignment, teachers could provide students with milestones on a weekly or fortnightly basis. Early in the semester (Week 2 or 3 ), the group should submit a draft storyboard via the Turnitin application. The inclusion of milestones will provide students with the opportunity to get timely feedback (Carless \& Boud, 2018; Hattie \& Timperley, 2007) and to apply feedback to improve the quality of their LDGM assignments. Furthermore, regular milestones can facilitate effective time management practices. Educators could also assist students with time management through the use of tools within the LMS (e.g., the calendar tool with alerts) or by using cloud services such as Google Drive to work collaboratively on their storyboards on a weekly basis without the need to meet face-to-face.

Educators can also assist students with help-seeking (Karabenick \& Gonida, 2018). In this study, students sought help from others, as well as from the Internet. Regarding help-seeking from others, teachers can nurture learning environments in which students feel safe and empowered to ask for help from their peers. This may be achieved through group-building activities (Mittelmeier, Rienties, Tempelaar, \& Whitelock, 2018) and instruction in active listening techniques (Weger, Castle, \& Emmett, 2010). Regarding helpseeking from the Internet, educators can curate resources relevant to LDGM, such as resources on how to develop storyboards, video production techniques, and copyright-free materials. Curation of resources will help students focus their efforts and minimise the workload and associated stress and anxiety reported for LGDM assignments (Coulson \& Frawley, 2017; Pearce \& Vanderlelie, 2016). Self-regulation strategies related to note-taking can also be enhanced through educator intervention. According to Hattie, Biggs, and Purdie (1996), students need to understand the purpose of note-taking and the conditions in which they will be required to apply the knowledge acquired from note-taking. When providing students with learning materials for their LDGM, educators can include study questions to guide students as they work through the materials.

The findings of this research may also have implications concerning the design of LGDM assignments according to learners' self-regulation skills. For instance, the science curriculum could be redesigned to include LGDM as a vehicle of learning, but also as an approach to developing communication skills in the digital space. Digital media skills are crucial for 21 st century professionals regardless of their discipline (Alexander, Adams, \& Cummins, 2016; Hobbs, 2017). First-year students could be introduced to simple ways to create LGDM, such as audio podcast, while second-year students could produce digital stories. In the third year, students could engage in the production of more sophisticated forms of digital media like video and blended media. Using this approach, first-year students could complete the Digital Media for Learning and Career items to gauge their attitudes towards LGDM and inform communication about why it is essential to learn through LGDM assignments.

Similarly, the self-regulation subscales described here (goal setting, time management, environment structuring, help-seeking from people, and help-seeking from the Internet) could be used for second- and third-year students and their scores compared to identify specific areas needing improvement. Also, aggregate scores could be used to set student profiles and inform group allocation at the beginning of the semester. The questionnaire can be completed within a relatively short timeframe (10-15 minutes) using tools like Google Forms, and a summary of student responses could be visualised within the classroom time frame. By using these scales in the classroom, educators can design activities which support student selfregulation learning processes. Researchers can also use the questionnaire instrument in conjunction with, 
for example, interviews and focus groups to get a deeper understanding of self-regulatory processes in LGDM assignments. Understanding self-regulation in LGDM assignments will also be an advantage in studying group interactions like co-regulation to provide better group experiences for students.

The next stage of our research will try to understand how students can use self-regulation learning strategies in LGDM assignments to enhance their performance and success. Analysis of data from the validated selfregulation questionnaire is currently in progress, using multivariate techniques including structural equations and multilevel modelling. Qualitative data collected via open-ended questions, individual interviews, and focus groups will help to get an in-depth understanding of self-regulation learning processes when using LGDM assignments in the classroom.

There are several limitations of the current study. Firstly, it used a four-point scale rather than a five-point or seven-point scale and did not capture students with truly neutral responses to the questionnaire. Notwithstanding this, several studies (e.g., Adelson \& McCoach, 2010; Chang, 1994) have found very few differences between the results of data obtained from four-point scales and the results of data captured from five-point scales. Secondly, because we tested constructs from the LDGM framework, we did not measure other variables such as self-efficacy, which is considered a motivational factor that works together with self-regulatory processes and which could provide additional explanatory power. A third limitation is that the data comes from students enrolled in blended learning courses, but the training for the LGDM assignment was in two modes - online and blended. As previously discussed, online learners use selfregulation strategies more often than blended learners do. Another limitation of the study is that data were gathered from cohorts of undergraduate students studying only science subjects. Future research should explore the extent to which findings from this research are generalisable to other program areas and institutions.

\section{References}

Adelson, J. L., \& McCoach, D. B. (2010). Measuring the mathematical attitudes of elementary students: The effects of a 4-point or 5-point Likert-type scale. Educational and Psychological Measurement, 70(5), 796-807. https://doi.org/10.1177/0013164410366694

Agustiani, H., Cahyad, S., \& Musa, M. (2016). Self-efficacy and self-regulated learning as predictors of students' academic performance. The Open Psychology Journal, 9(1), 1-6. https://doi.org/ 10.2174/1874350101609010001

Ajzen, I. (1996). The directive influence of attitudes on behavior. In P. M. G. J. A. Bargh (Ed.), The psychology of action: Linking cognition and motivation to behavior (pp. 385-403). New York, NY: Guilford Press.

Alexander, B., Adams, S., \& Cummins, M. (2016). Digital literacy: An NMC Horizon project strategic brief(Vol. 3.3). Austin, TX: The New Media Consortium. Retrieved from http://cdn.nmc.org/media/2016-nmc-horizon-strategic-brief-digital-literacy.pdf

Anderson, J. (2013a). Active learning through student film: A case study of cultural geography. Journal of Geography in Higher Education, 37(3), 385-398. https://doi.org/10.1080/03098265.2013.792041

Anderson, J. (2013b). Evaluating student-generated film as a learning tool for qualitative methods: Geographical "drifts" and the city. Journal of Geography in Higher Education, 37(1), 136-146. https://doi.org/10.1080/03098265.2012.694070

Artino, A. R., Jr., \& Stephens, J. M. (2009). Academic motivation and self-regulation: A comparative analysis of undergraduate and graduate students learning online. The Internet and Higher Education, 12(3-4), 146-151. https://doi.org/10.1016/j.iheduc.2009.02.001

Azevedo, R., \& Cromley, J. G. (2004). Does training on self-regulated learning facilitate students' learning with hypermedia? Journal of Educational Psychology, 96(3), 523-535. https://doi.org/10.1037/0022-0663.96.3.523

Bandura, A. (1986). The explanatory and predictive scope of self-efficacy theory. Journal of Social and Clinical Psychology, 4(3), 359-373. https://doi.org/10.1521/jscp.1986.4.3.359

Bandura, A. (1991). Social cognitive theory of self-regulation. Organizational Behavior and Human Decision Processes, 50(2), 248-287. https://doi.org/10.1016/0749-5978(91)90022-L

Barak, M., Hussein-Farraj, R., \& Dori, Y. J. (2016). On-campus or online: Examining self-regulation and cognitive transfer skills in different learning settings. International Journal of Educational Technology in Higher Education, 13(1), 1-18. https://doi.org/10.1186/s41239-016-0035-9 
Barnard, L., Lan, W. Y., To, Y. M., Paton, V. O., \& Lai, S.-L. (2009). Measuring self-regulation in online and blended learning environments. The Internet and Higher Education, 12(1), 1-6. https://doi.org/10.1016/i.iheduc.2008.10.005

Barnard, L., Paton, V., \& Lan, W. (2008). Online self-regulatory learning behaviors as a mediator in the relationship between online course perceptions with achievement. The International Review of Research in Open and Distributed Learning, 9(2), 1-11. https://doi.org/10.19173/irrodl.v9i2.516

Barnard-Brak, L., Paton, V. O., \& Lan, W. Y. (2010). Profiles in self-regulated learning in the online learning environment. The International Review of Research in Open and Distributed Learning, 11(1), 61-80. https://doi.org/10.19173/irrodl.v11i1.769

Bergamin, P. B., Ziska, S., Werlen, E., \& Siegenthaler, E. (2012). The relationship between flexible and self-regulated learning in open and distance universities. The International Review of Research in Open and Distributed Learning, 13(2), 101-123. https://doi.org/10.19173/irrodl.v13i2.1124

Braun, M. (2017). Comparative evaluation of online and in-class student team presentations. Journal of University Teaching \& Learning Practice, 14(3), 3. Retrieved from https://ro.uow.edu.au/jutlp/vol14/iss3/3

Broadbent, J. (2017). Comparing online and blended learner's self-regulated learning strategies and academic performance. The Internet and Higher Education, 33(1), 24-32. https://doi.org/10.1016/j.iheduc.2017.01.004

Broadbent, J., \& Poon, W. (2015). Self-regulated learning strategies \& academic achievement in online higher education learning environments: A systematic review. The Internet and Higher Education, 27(3), 1-13. https://doi.org/10.1016/j.iheduc.2015.04.007

Brown, J. M., Miller W. R., \& Lawendowski, L. A. (1999).The self-regulation questionnaire. In L. VandeCreek \& T. L Jackson (Eds.), Innovations in clinical practice: A sourcebook (Vol. 17, pp. 281-292). Sarasota, FL: Professional Resource Press/Professional Resource Exchange.

Busch, M. (1993). Using Likert scales in L2 research: A researcher comments. TESOL Quarterly, 27, 733-726. https://doi.org/10.2307/3587408

Campbell, L. O., \& Cox, T. D. (2018). Digital video as a personalized learning assignment: A qualitative study of student authored video using the ICSDR Model. Journal of the Scholarship of Teaching and Learning, 18(1), 11-24. https://doi.org/10.14434/josotl.v18i1.21027

Carless, D., \& Boud, D. (2018). The development of student feedback literacy: Enabling uptake of feedback. Assessment \& Evaluation in Higher Education, 43(8), 1315-1325. https://doi.org/10.1080/02602938.2018.1463354

Cattell, R. B. (1966). The scree test for the number of factors. Multivariate Behavioral Research, 1(2), 245-276. https://doi.org/10.1207/s15327906mbr0102 10

Chang, L. (1994). A psychometric evaluation of 4-point and 6-point Likert-type scales in relation to reliability and validity. Applied Psychological Measurement, 18(3), 205-215. https://doi.org/10.1177/014662169401800302

Chen, C. S. (2002). Self-regulated learning strategies and achievement in an introduction to information systems course. Information Technology, Learning, and Performance Journal, 20(1), 11-23. Retrieved from https://www.learntechlib.org/p/95111/

Cho, M.-H., \& Heron, M. L. (2015). Self-regulated learning: The role of motivation, emotion, and use of learning strategies in students' learning experiences in a self-paced online mathematics course. Distance Education, 36(1), 80-99. https://doi.org/10.1080/01587919.2015.1019963

Cleary, T. J., \& Zimmerman, B. J. (2012). A cyclical self-regulatory account of student engagement: Theoretical foundations and applications. In S. L. Christenson, A. L. Reschly, \& C. Wylie (Eds.), Handbook of research on student engagement (pp. 237-257). Boston, MA: Springer US.

Costello, A. B., \& Osborne, J. W. (2005). Best practices in exploratory factor analysis: Four recommendations for getting the most from your analysis. Practical assessment, Research \& Evaluation, 10(7), 1-9. https://doi.org/10.4135/9781412995627.d8

Coulson, S., \& Frawley, J. (2017). Student-generated multimedia for supporting learning in an undergraduate physiotherapy course. In H. Partridge, K. Davis, \& J. Thomas (Eds.), Me, Us, IT! Proceedings ASCILITE2017: 34th International Conference on Innovation, Practice and Research in the Use of Educational Technology in Tertiary Education (pp. 235-244). Retrieved from http://2017conference.ascilite.org/wp-content/uploads/2017/11/Full-COULSON.pdf

Cox, A. M., Vasconcelos, A. C., \& Holdridge, P. (2010). Diversifying assessment through multimedia creation in a non-technical module: reflections on the MAIK project. Assessment \& Evaluation in Higher Education, 35(7), 831-846. https://doi.org/10.1080/02602930903125249 
Dabbagh, N., \& Kitsantas, A. (2004). Supporting self-regulation in student-centered web-based learning environments. International Journal on E-Learning, 3(1), 40-47. Retrieved from https://www.learntechlib.org/primary/p/4104/

Dörrenbächer, L., \& Perels, F. (2016). Self-regulated learning profiles in college students: Their relationship to achievement, personality, and the effectiveness of an intervention to foster selfregulated learning. Learning and Individual Differences, 51(2), 229-241. https://doi.org/10.1016/j.lindif.2016.09.015

Dunnigan, J. E. (2018). The relationship of self-regulated learning and academic risk factors to academic performance in community college online mathematics courses (Doctoral dissertation). Retrieved from https://digitalcommons.spu.edu/soe etd/29/

Elliot, A. J., \& Harackiewicz, J. M. (1994). Goal setting, achievement orientation, and intrinsic motivation: A mediational analysis. Journal of Personality and Social Psychology, 66(5), 968-980. https://doi.org/10.1037/0022-3514.66.5.968

Fazio, R. H., \& Roskos-Ewoldsen, D. R. (2005). Acting as we feel: When and how attitudes guide behavior. In T. C. B. M. C. Green (Ed.), Persuasion: Psychologicalinsights and perspectives (2nd ed.) (pp. 41-62). Thousand Oaks, CA: Sage Publications, Inc.

Garrison, R. (2000). Theoretical challenges for distance education in the 21 st century: A shift from structural to transactional issues. The International Review of Research in Open and Distributed Learning, 1(1), 1-17. https://doi.org/10.19173/irrodl.v1i1.2

Georgiou, H., Nielsen, W., Doran, Y., Turney, A., \& Jones, P. (2017, August). Analysing studentgenerated digital media in science. In Proceedings of The Australian Conference on Science and Mathematics Education (formerly UniServe Science Conference) (pp. 57-58). Retrieved from https://openjournals.library.sydney.edu.au/index.php/IISME/article/view/10793

Greene, H., \& Crespi, C. (2012). The value of student-created videos in the college classroom-an exploratory study in marketing and accounting. International Journal of Arts and Sciences, 5(1), 273283. https://www.researchgate.net/publication/266587463

Hadwin, A. F., Oshige, M., Gress, C. L., \& Winne, P. H. (2010). Innovative ways for using gStudy to orchestrate and research social aspects of self-regulated learning. Computers in Human Behavior, 26(5), 794-805. https://doi.org/10.1016/j.chb.2007.06.007

Hakkarainen, K. (2009). A knowledge-practice perspective on technology-mediated learning. International Journal of Computer-Supported Collaborative Learning, 4(2), 213-231. https://doi.org/10.1007/s11412-009-9064-x

Harrington, D. (2009). Confirmatory factor analysis: New York, NY: Oxford University Press.

Hattie, J., Biggs, J., \& Purdie, N. (1996). Effects of learning skills interventions on student learning: A meta-analysis. Review of Educational Research, 66(2), 99-136. https://doi.org/10.3102/00346543066002099

Hattie, J., \& Timperley, H. (2007). The power of feedback. Review of Educational Research, 77(1), 81112. https://doi.org/10.3102/003465430298487

Henson, R. K., \& Roberts, J. K. (2006). Use of exploratory factor analysis in published research: Common errors and some comment on improved practice. Educational and Psychological Measurement, 66(3), 393-416. https://doi.org/10.1177/0013164405282485

Hoban, G., \& Nielsen, W. (2013). Learning science through creating a 'Slowmation': A case study of preservice primary teachers. International Journal of Science Education, 35(1), 119-146. https://doi.org/10.1080/09500693.2012.670286

Hoban, G., Nielsen, W., \& Shepherd, A. (2015). Student-generated digital media in science education: Learning, explaining and communicating content. London: Routledge.

Hobbs, R. (2017). Create to learn: Introduction to digital literacy. Hoboken, NJ: John Wiley \& Sons.

Hodges, C. (2005). Self-regulation in web-based courses: A review and the need for research. Quarterly Review of Distance Education, 6(4), 375-383. Retrieved from https://www.infoagepub.com/qrdeissue.html? $\mathrm{i}=\mathrm{p} 54 \mathrm{c} 3 \mathrm{cb} 096 \mathrm{fccd}$

Horn, J. L. (1965). A rationale and test for the number of factors in factor analysis. Psychometrika, 30(2), 179-185. https://doi.org/10.1007/BF02289447

Inan, F., Yukselturk, E., Kurucay, M., \& Flores, R. (2017). The impact of self-regulation strategies on student success and satisfaction in an online course. International Journal on E-learning, 16(1), 23 32. Retrieved from https://www.learntechlib.org/primary/p/147296/

Isaac, S., \& Michael, W. B. (1995). Handbook in research and evaluation: A collection of principles, methods, and strategies useful in the planning, design, and evaluation of studies in education and the behavioral sciences (3rd ed.). San Diego, CA: Edits Publishers. 
Jenson, J. D. (2011). Promoting self-regulation and critical reflection through writing students' use of electronic portfolio. International Journal of ePortfolio, 1(1), 49-60. Retrieved from http://www.theijep.com/pdf/IJEP19.pdf

Kaiser, H. F. (1960). The application of electronic computers to factor analysis. Educational and Psychological Measurement, 20(1), 141-151. https://doi.org/10.1177/001316446002000116

Karabenick, S. A., \& Gonida, E. N. (2018). Academic help seeking as a self-regulated learning strategy: Current issues, future directions. In D. H. Schunk \& J. A. Greene (Eds.), Educational Psychology Handbook Series: Handbook of self-regulation of learning and performance (2nd ed.) (pp. 421-433). New York, NY: Routledge/Taylor \& Francis Group.

Kauffman, D. F. (2004). Self-regulated learning in web-based environments: Instructional tools designed to facilitate cognitive strategy use, metacognitive processing, and motivational beliefs. Journal of Educational Computing Research, 30(1-2), 139-161. https://doi.org/10.2190/AX2D-Y9VM-V7PXOTAD

Kearney, M. (2009). Towards a learning design for student-generated digital storytelling. In Proceedings of The Future of Learning Design Conference (pp. 28-37), Wollongong, Australia: University of Wollongong. Retrieved from http://ro.uow.edu.au/fld/09/Program/4/

Kearney, M. (2013). Learner-generated digital video: Using ideas videos in teacher education. Journal of Technology and Teacher Education, 21(3), 321-336. Retrieved from https://www.learntechlib.org/primary/p/41935/

Kearney, M., Pressick-Kilborn, K. \& Maher, D. (2012). Driving pre-service science teachers' TPACK development through their generative use of digital video. In P. Resta (Ed.), Proceedings of SITE 2012. Society for Information Technology \& Teacher Education International Conference (pp. 13811388). Waynesville, NC: Association for the Advancement of Computing in Education (AACE). Retrieved from https://www.learntechlib.org/primary/p/39774/

Kearney, M., \& Schuck, S. (2005). Students in the director's seat: Teaching and learning with studentgenerated video. In P. Kommers \& G. Richards (Eds.), Proceedings of ED-MEDIA 2005--World Conference on Educational Multimedia, Hypermedia \& Telecommunications (pp. 2864-2871). Waynesville, NC: Association for the Advancement of Computing in Education (AACE). Retrieved from https://www.learntechlib.org/primary/p/20518/.

Kocdar, S., Karadeniz, A., Bozkurt, A., \& Buyuk, K. (2018). Measuring self-regulation in self-paced open and distance learning environments. The International Review of Research in Open and Distributed Learning, 19(1), 27-43. https://doi.org/10.19173/irrodl.v19i1.3255

Kuo, Y.-C., Walker, A. E., Schroder, K. E., \& Belland, B. R. (2014). Interaction, internet self-efficacy, and self-regulated learning as predictors of student satisfaction in online education courses. The Internet and Higher Education, 20(2), 35-50. https://doi.org/10.1016/j.iheduc.2013.10.001

Lee, S. Y., \& Brand, J. L. (2010). Can personal control over the physical environment ease distractions in office workplaces? Ergonomics, 53(3), 324-335. https://doi.org/10.1080/00140130903389019

Lynch, R., \& Dembo, M. (2004). The relationship between self-regulation and online learning in a blended learning context. The International Review of Research in Open and Distributed Learning, 5(2), 1-16. Retrieved from https://www.learntechlib.org/p/49426/

McClain, E. K. (2015). The effects of the use of a self-monitoring form on achievement and selfregulated learning in a developmental mathematics course (Doctoral dissertation, University of Kansas). Retrieved from https://kuscholarworks.ku.edu/handle/1808/19508

Meece, J. L., Blumenfeld, P. C., \& Hoyle, R. H. (1988). Students' goal orientations and cognitive engagement in classroom activities. Journal of Educational Psychology, 80(4), 514-523. https://doi.org/10.1037/0022-0663.80.4.514

Miller, D. A. (2015). Learning how students learn: An exploration of self-regulation strategies in a twoyear college general chemistry class. Journal of College Science Teaching, 44(3), 11-16. Retrieved from https://www.jstor.org/stable/43631933

Mittelmeier, J., Rienties, B., Tempelaar, D., \& Whitelock, D. (2018). Overcoming cross-cultural group work tensions: Mixed student perspectives on the role of social relationships. Higher Education, 75(1), 149-166. https://doi.org/10.1007/s10734-017-0131-3

Musburger, R. B., \& Kindem, G. (2012). Introduction to media production: The path to digital media production. Burlington, MA: Focal Press.

Nielsen, W., Hoban, G., \& Hyland, C. (2017). Pharmacology students' perceptions of creating multimodal digital explanations. Chemistry Education Research and Practice, 18(2), 329-339. https://doi.org/10.1039/C6RP00244G 
Nota, L., Soresi, S., \& Zimmerman, B. J. (2004). Self-regulation and academic achievement and resilience: A longitudinal study. International Journal of Educational Research, 41(3), 198-215. https://doi.org/10.1016/j.ijer.2005.07.001

O'Rourke, N., Psych, R., \& Hatcher, L. (2013). A step-by-step approach to using SAS for factor analysis and structural equation modelling. Cary, NC: SAS Institute.

Pearce, K. L. (2014). Undergraduate creators of video, animations and blended media: The students' perspective. In Proceedings of The Australian Conference on Science and Mathematics Education (pp. 156-162). Retrieved from https://openjournals.library.sydney.edu.au/index.php/IISME/article/viewFile/7769/8079

Pearce, K. L., \& Vanderlelie, J. J. (2016). Teaching and evaluating graduate attributes in multimedia science-based assessment task. In Proceedings of The Australian Conference on Science and Mathematics Education (pp. 215-225). Retrieved from https://openjournals.library.sydney.edu.au/index.php/IISME/article/view/10783/11328

Pintrich, P. R. (2004). A conceptual framework for assessing motivation and self-regulated learning in college students. Educational Psychology Review, 16(4), 385-407. https://doi.org/10.1007/s10648004-0006-X

Pintrich, P. R., Smith, D. A. F., Garcia, T., \& McKeachie, W. J. (1991). A manual for the use of the motivated strategies for learning questionnaire (MSLQ). Ann Arbor: University of Michigan. Retrived from ERIC database. (ED338122)

Pintrich, P. R., Smith, D. A., Garcia, T., \& McKeachie, W. J. (1993). Reliability and predictive validity of the Motivated Strategies for Learning Questionnaire (MSLQ). Educational and Psychological Measurement, 53(3), 801-813. https://doi.org/10.1177/0013164493053003024

Pintrich, P. R., \& Zusho, A. (2007). Student motivation and self-regulated learning in the college classroom. In R. P. Perry \& J. C. Smart (Eds.), The scholarship of teaching and learning in higher education: An evidence-based perspective (pp. 731-810). Dordrecht, Netherlands: Springer.

Potter, J., \& McDougall, J. (2017). Digital media, culture and education: Theorising third space literacies. London: Palgrave Macmillan.

Powell, L., \& Robson, F. (2014). Learner-generated podcasts: a useful approach to assessment? Innovations in Education and Teaching International, 51(3), 326-337. https://doi.org/10.1080/14703297.2013.796710

Reyna, J., Hanham, J., \& Meier, P. (2017). A taxonomy of digital media types for learner-generated digital media assignments. E-learning and Digital Media, 14(6), 309-322. https://doi.org/10.1177/2042753017752973

Reyna, J., Hanham, J., \& Meier, P. (2018a). The Internet explosion, digital media principles and implications to communicate effectively in the digital space. E-learning and Digital Media, 15(1), 3652. https://doi.org/10.1177/2042753018754361

Reyna, J., Hanham, J. \& Meier, P. (2018b). A methodological approach to evaluate the effectiveness of learner-generated digital media (LGDM) assignments in science education. In T. Bastiaens, J. Van Braak, M. Brown, L. Cantoni, M. Castro, R. Christensen, ... O. Zawacki-Richter (Eds.), Proceedings of EdMedia: World Conference on Educational Media and Technology (pp. 303-314). Waynesville, NC: Association for the Advancement of Computing in Education (AACE). Retrieved from https://www.learntechlib.org/primary/p/184211/.

Reyna, J., Hanham, J., \& Meier, P. (2018c). Theoretical considerations to design learner-generated digital media (LGDM) assignments in higher education. In Proceedings of the 12th International Technology, Education and Development Conference (pp. 1285-1292). Retrieved from https://library.iated.org/view/REYNA2018ORE

Reyna, J., Horgan, F., Ramp, D., \& Meier, P. (2017). Using learner-generated digital media (LGDM) as an assessment tool in geological sciences. In Proceedings of the 11th International Conference on Technology, Education and Development (pp. 40-50). Retrieved from https://library.iated.org/view/REYNA2017USI

Reyna, J., \& Meier, P. (2018). A practical model for implementing digital media assessments in tertiary science education. American Journal of Educational Research, 6(1), 27-31. https://doi.org/10.12691/education-6-1-4

Reyna, J., Meier, P., Geronimo, F., \& Rodgers, K. (2016). Implementing digital media presentations as assessment tools for pharmacology students. American Journal of Educational Research, 4(14), 983991. https://doi.org/10.12691/education-4-14-1 
Richardson, M., Abraham, C., \& Bond, R. (2012). Psychological correlates of university students' academic performance: A systematic review and meta-analysis. Psychological Bulletin, 138(2), 353387. https://doi.org/10.1037/a0026838

Schermelleh-Engel, K., Moosbrugger, H., \& Müller, H. (2003). Evaluating the fit of structural equation models: Tests of significance and descriptive goodness-of-fit measures. Methods of Psychological Research Online, 8(2), 23-74. Retrieved from https://psycnet.apa.org/record/2003-08119-003

Schunk, D. H., \& Zimmerman, B. (2011). Handbook of self-regulation of learning and performance: New York, NY: Taylor \& Francis. https://doi.org/10.1207/s15326985ep3204 1

Schunk, D. H., \& Zimmerman, B. J. (1997). Social origins of self-regulatory competence. Educational Psychologist, 32(4), 195-208. https://doi.org/10.1207/s15326985ep3204_1

Sørensen, B. H., \& Levinsen, K. T. (2014). Digital production and students as learning designers. Designs for Learning, 7(1), 54-74. Retrieved from http://vbn.aau.dk/en/publications/digital-production-andstudents-as-learning-designers(f62b382c-65a2-465d-a304-9777aabd1ad8).html

$\mathrm{Su}$, Y., Zheng, C., Liang, J.-C., \& Tsai, C.-C. (2018). Examining the relationship between English language learners' online self-regulation and their self-efficacy. Australasian Journal of Educational Technology, 34(3), 105-121. https://doi.org/10.14742/ajet.3548

Tashakkori, A., \& Teddlie, C. (2010). Sage handbook of mixed methods in social \& behavioural research. Los Angeles, CA: Sage Publications.

Thompson, B. (2004). Exploratory and confirmatory factor analysis: Understanding concepts and applications. Washington, DC: American Psychological Association.

Van Dijck, J. (2009). Users like you? Theorizing agency in user-generated content. Media, Culture, and Society, 31(1), 41. https://doi.org/10.1177/0163443708098245

Van Dijk, A. M., \& Lazonder, A. W. (2016). Scaffolding students' use of learner-generated content in a technology-enhanced inquiry learning environment. Interactive Learning Environments, 24(1), 194204. https://doi.org/10.1080/10494820.2013.834828

Wang, C. H., Shannon, D. M., \& Ross, M. E. (2013). Students' characteristics, self-regulated learning, technology self-efficacy, and course outcomes in online learning. Distance Education, 34(3), 302323. https://doi.org/10.1080/01587919.2013.835779

Weger, H., Jr., Castle, G. R., \& Emmett, M. C. (2010). Active listening in peer interviews: The influence of message paraphrasing on perceptions of listening skill. International Journal of Listening, 24(1), 34-49. https://doi.org/10.1080/10904010903466311

Weinstein, C. E., \& Palmer, D. R. (2002). LASSI user's manual: For those administering the Learning and Study Strategies Inventory. Clearwater, FL: H \& H Publishing.

Wigfield, A., \& Eccles, J. S. (2000). Expectancy-value theory of achievement motivation. Contemporary Educational Psychology, 25(1), 68-81. https://doi.org/10.1006/ceps.1999.1015

Williams, B., Onsman, A., \& Brown, T. (2010). Exploratory factor analysis: A five-step guide for novices. Australasian Journal of Paramedicine, 8(3), 1-13. https://doi.org/10.33151/ajp.8.3.93

Winne, P. H., \& Hadwin, A. F. (1998). Studying as self-regulated learning. Metacognition in Educational Theory and Practice, 93, 27-30. Retrieved from https://psycnet.apa.org/record/1998-07283-011

Yukselturk, E., \& Bulut, S. (2007). Predictors for student success in an online course. Journal of Educational Technology \& Society, 10(2), 71-83. Retrieved from https://www.jets.net/ETS/journals/10 2/7.pdf

Zhu, Y., Au, W., \& Yates, G. (2016). University students' self-control and self-regulated learning in a blended course. The Internet and Higher Education, 30, 54-62. https://doi.org/10.1016/j.iheduc.2016.04.001

Zimmerman, B. J. (1989). A social cognitive view of self-regulated academic learning. Journal of Educational Psychology, 81(3), 329-339. https://doi.org/10.1037/0022-0663.81.3.329

Zimmerman, B. J. (1995). Self-regulation involves more than metacognition: A social cognitive perspective. Educational Psychologist, 30(4), 217-221. https://doi.org/10.1207/s15326985ep3004_8

Zimmerman, B. J. (1998). Developing self-fulfilling cycles of academic regulation: An analysis of exemplary instructional models. In D. H. Schunk \& B. J. Zimmerman (Eds.), Self-regulated learning: From teaching to self-reflective practice (pp. 1-19). New York, NY: Guilford Publications.

Zimmerman, B. J. (2000). Self-efficacy: An essential motive to learn. Contemporary Educational Psychology, 25(1), 82-91. https://doi.org/10.1006/ceps.1999.1016

Zimmerman, B. J. (2002). Achieving academic excellence: A self-regulatory perspective. In M. Ferrari (Ed.), The pursuit of excellence through education (pp. 85-110). Mahwah, NJ: Lawrence Erlbaum. 
Zimmerman, B. J. (2008). Investigating self-regulation and motivation: Historical background, methodological developments, and future prospects. American Educational Research Journal, 45(1), 166-183. https://doi.org/10.3102/0002831207312909

Zimmerman, B. J., \& Schunk, D. H. (2011). Self-regulated learning and performance. In Handbook of self-regulation of learning and performance (pp. 1-12). New York, NY: Taylor \& Francis

Zimmerman, B. J., \& Tsikalas, K. E. (2005). Can computer-based learning environments (CBLEs) be used as self-regulatory tools to enhance learning? Educational Psychologist, 40(4), 267-271. https://doi.org/10.1207/s15326985ep4004_8

Corresponding author: Jorge Reyna, jorge.reyna@uts.edu.au

Please cite as: Reyna, J., Hanham, J., Vlachopoulos, P., \& Meier, P. (2019). Using factor analysis to validate a questionnaire to explore self-regulation in learner-generated digital media (LGDM) assignments in science education. Australasian Journal of Educational Technology, 35(5), 128-152. https://doi.org/10.14742/ajet.4514 


\section{Appendix A}

Table

Measuring self-regulation in online and blended learning environments (Barnard et al., 2009, pp. 5 \& 6)

\begin{tabular}{|c|c|}
\hline Subscale & Item \\
\hline Goal setting & $\begin{array}{l}\text { I set standards for my assignments in online courses. } \\
\text { I set short-term (daily or weekly) goals as well as long-term goals } \\
\text { (monthly or for the semester). } \\
\text { I keep a high standard for my learning in my online courses. } \\
\text { I set goals to help me manage studying time for my online courses. } \\
\text { I don't compromise the quality of my work because it is online. }\end{array}$ \\
\hline Environment structuring & $\begin{array}{l}\text { I choose the location where I study to avoid too much distraction. } \\
\text { I find a comfortable place to study. } \\
\text { I know where I can study most efficiently for online courses. } \\
\text { I choose a time with few distractions for studying for my online } \\
\text { courses. }\end{array}$ \\
\hline Task strategies & $\begin{array}{l}\text { I try to take more thorough notes for my online courses because notes } \\
\text { are even more important for learning online than in a regular } \\
\text { classroom. } \\
\text { I read aloud instructional materials posted online to fight against } \\
\text { distractions. } \\
\text { I prepare my questions before joining in the chat room and discussion. } \\
\text { I work extra problems in my online courses in addition to the assigned } \\
\text { ones to master the course content. }\end{array}$ \\
\hline Time management & $\begin{array}{l}\text { I allocate extra studying time for my online courses because I know it } \\
\text { is time-demanding. } \\
\text { I try to schedule time everyday or every week to study for my online } \\
\text { courses, and I observe the schedule. } \\
\text { Although we don't have to attend daily classes, I still try to distribute } \\
\text { my studying time evenly across days. }\end{array}$ \\
\hline Help-seeking & $\begin{array}{l}\text { I find someone who is knowledgeable in course content so that I can } \\
\text { consult with him or her when I need help. } \\
\text { I share my problems with my classmates online so we know what we } \\
\text { are struggling with and how to solve our problems. } \\
\text { If needed, I try to meet my classmates face-to-face. } \\
\text { I am persistent in getting help from the instructor through email. }\end{array}$ \\
\hline Self-evaluation & $\begin{array}{l}\text { I summarise my learning in online courses to examine my } \\
\text { understanding of what I have learned. } \\
\text { I ask myself a lot of questions about the course material when studying } \\
\text { for an online course. } \\
\text { I communicate with my classmates to find out how I am doing in my } \\
\text { online classes. } \\
\text { I communicate with my classmates to find out what I am learning that } \\
\text { is different from what they are learning. }\end{array}$ \\
\hline
\end{tabular}




\section{Appendix B}

Table

Questions on digital media for learning, digital media for a career, assignment motivation, assignment ownership and self-regulation

Subscale
Digital media for learning
(DML)
Digital media for a career
(DMC)

Assignment motivation (AM) Item

1. I learn about the subject content while creating digital media.

2. Learning the subject content using digital media is good.

3. Digital media helped me to learn the subject content.

4. I enjoy learning the subject content using digital media.

5. Digital media skills are important for my career.

6. I will apply digital media skills in my future career.

7. Having digital media skills is an advantage for my career.

8. Digital media skills are needed now regardless the career you are in.

9. I am driven by marks.

10. If the assignment is not worth too many marks I will put less effort into it.

11. I will perform the best I can no matter how many marks the assignment is worth.

12. I am driven by learning rather than marks.

Assignment ownership (AO)

13. I feel a high sense of accomplishment when producing a digital media assignment.

14. Sharing a digital media assignment online makes me feel a high level of accomplishment.

15. I would like to produce a digital media assignment that I can be proud of.

Task strategies (TS)*

16. I take notes from the digital media lecture to be more prepared for the task.

17. I take notes from the digital media workshop to be more prepared for the task.

18. I visit the digital media resources inside the learning management system.

Goal setting (GS)*

19. I visit additional resources online about digital media.

20. I set standards for my assignments.

21. I set goals to help me manage time for my assignment.

22. I set short-term goals when preparing my digital media assignment.

23. I set long-term goals when preparing my digital media assignment.

Environment structuring $(\mathrm{ES})^{*}$

24. I choose the location where I work on my digital media assignment to avoid distraction.

25. I find a comfortable place to work on my digital media assignment.

26. I know where I can work most efficiently for my digital media assignment.

27. I choose a time with few distractions for working for my digital media assignment.

Time management $(\mathrm{TM})^{*} \quad 28$. I allocate extra time for my digital media assignment.

29. I schedule regular times a week to work on my digital media assignment.

30. I helped managed my time efficiently, so I was not rushing around to finish at the last minute.

31. I follow my planned schedule for completing the digital media project.

Help-seeking (HS)*

32. I find people who are knowledgeable in subject content so that I can ask them for help.

33. I share the difficulties I am having with the digital media assignment with my classmates.

34. I am persistent in getting help for my assignment from the instructor

35. I seek help on the Internet about my assignment topic.

36. I seek help on the Internet about digital media creation. 
Self-evaluation (SE)*

37. I ask myself questions about the assignment material when preparing the digital media assignment.

38. I check with my classmates to find out how I am doing in my assignment.

39. I check with my classmates to find out what I am learning that is different from what they are learning.

40. I reflect on what I have learnt on my assignment.

Note. *Denotes self-regulation. 


\section{Appendix C}

Table

Standardised solutions by CFA for the ten-factor model

\begin{tabular}{|c|c|c|c|c|c|c|c|c|c|c|}
\hline \multirow[b]{2}{*}{ Item } & \multicolumn{9}{|c|}{ Factor } & \multirow[b]{2}{*}{ HSI } \\
\hline & DML & DMC & $\mathbf{A M}$ & AO & TS & GS & ES & TM & HSP & \\
\hline 3 & .82 & & & & & & & & & \\
\hline 4 & .75 & & & & & & & & & \\
\hline 2 & .66 & & & & & & & & & \\
\hline 1 & .56 & & & & & & & & & \\
\hline 8 & & .85 & & & & & & & & \\
\hline 5 & & .84 & & & & & & & & \\
\hline 6 & & .82 & & & & & & & & \\
\hline 7 & & .65 & & & & & & & & \\
\hline 11 & & & .85 & & & & & & & \\
\hline 10 & & & .82 & & & & & & & \\
\hline 13 & & & & .84 & & & & & & \\
\hline 14 & & & & .82 & & & & & & \\
\hline 16 & & & & & .90 & & & & & \\
\hline 17 & & & & & .86 & & & & & \\
\hline 18 & & & & & .57 & & & & & \\
\hline 22 & & & & & & .82 & & & & \\
\hline 20 & & & & & & .76 & & & & \\
\hline 21 & & & & & & .64 & & & & \\
\hline 26 & & & & & & & .73 & & & \\
\hline 27 & & & & & & & .70 & & & \\
\hline 24 & & & & & & & .70 & & & \\
\hline 25 & & & & & & & .60 & & & \\
\hline 31 & & & & & & & & .82 & & \\
\hline 30 & & & & & & & & .78 & & \\
\hline 29 & & & & & & & & .72 & & \\
\hline 38 & & & & & & & & & .82 & \\
\hline 39 & & & & & & & & & .72 & \\
\hline 33 & & & & & & & & & .71 & \\
\hline 32 & & & & & & & & & .63 & \\
\hline 34 & & & & & & & & & .56 & \\
\hline 36 & & & & & & & & & & .84 \\
\hline 35 & & & & & & & & & & .78 \\
\hline
\end{tabular}

